\title{
Mission studies at South African higher education institutions: An ethical and decolonial perspective in the quest to 'colour' the discipline
}

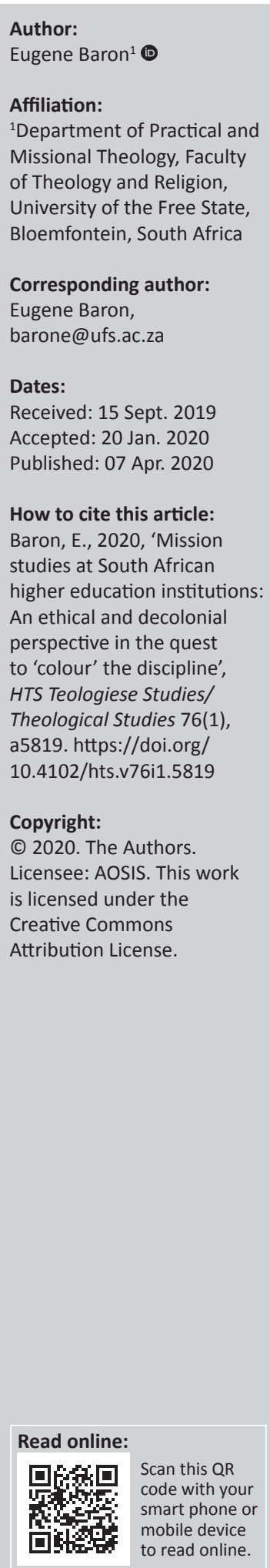

The recent debate on decolonisation calls for all academic disciplines, including missiology modules, at public universities to reflect on its content, curriculum and pedagogies. However, the danger is always that to 'de-...' might lead to an exclusivist and essentialist pattern of a person or institution, and an act that does not take all epistemic communities seriously. The author argues in this article that such tendencies would not be conducive in South Africa, a country with a rich heritage of various cultures. Epistemologies at public universities should embrace all cultures in order to be relevant and transformative. The article oscillates between essentialism in social, racial identities and non-essentialism thereof - primarily contending for the inclusion and appreciation of all social and cultural identities in South African curriculum and content for higher education, in particular, the cultural tradition and heritage among the so-called 'coloured' communities. The article reassesses the contributions of theologians towards racial and ethnic identity. The author uses one particular 'racial identity' as a case study for racial essentialism and to argue for an inclusive approach in mission education. The article conclusively argues for the re-imagination and inclusion of 'coloured' as an African identity in the discipline of missiology.

Keywords: Black; African; Essentialism; Multiculturalism; Mission.

\section{Introduction}

What ${ }^{1}$ is the state of affairs in South African mission education at public higher education institutions? Is there a place for 'colouring'?2 This question has particularly to do with the interlocutors ${ }^{3}$ and the conversation partners in mission studies in a post-apartheid South Africa. There has been a considerable amount of responses since the seminal work of the renowned missiologist David J. Bosch (Transforming Mission 1991) and his discussion on mission as 'contextualization' (Bosch 1991:420-431) and 'inculturation' (Bosch 1991:447-456). Moreover, in the more recent response on contextual mission from the World Council of Churches' (WCC) mission statement: 'Together towards Life (TTL): Mission and Evangelism in Changing Landscapes' (Keum 2013,) the contributors emphasise that mission should no longer be about going to the margins, but to conduct the mission from the margins.

Nonetheless, the recent discussion on decolonisation requires all academic disciplines, including missiology modules at public universities, to critically reflect on its content, curriculum and pedagogies. This warrants for a critical reflection on the content, the curriculum and the pedagogical strategies of missiology. The recent (2019) mission conference of the Southern African Missiological Society (SAMS) engaged in a robust discussion on the transformation of mission(s) education at all public universities in South Africa. What has not been critically reflected on is the notion of 'African' and what it would mean when the conference reflected on the transformation of mission education in the African context. This can be observed through the various papers that were presented, and particularly the anecdotes and narratives that were used when presenters made references to the South African society - as if there was no underlying tension in terms of 1.Dr Eugene Baron (PhD) in a lecturer in the Department of Practical and Missional Theoology at the University of the Free State. He is also
the Editorial Administrator of the missions journal Missionalia. He can be contacted at barone@ufs.ac.za. 2.The word 'colouring' denotes a multi-racial and multi-cultural approach. Nonetheless, the author does not argue for the advancement of a particular 'colour' (i.e. race) because that would exactly feed into the meta-narrative that the author is against - but the inclusion - of all racial and ethnic heritage (i.e. the practice to use a range of 'colours'), the variant stories (cf. Achebe 2000) to narrate the African story.

3.In this article, the author argues for the engagement of the cultural identity of the so-called 'coloured' people of South Africa. 
racial and ethnic identities. It was also quite recently (February 2019) - during a conference discussion that focused on a group of 'marginalised' people - that the author noticed that one of the respondents failed to echo a deep appreciation for the kind of diversities (cultural and racial) that might exist within such a group of homeless people in the African context.

Tshaka (2007:533-548) raised this particular concern in his conversation with John Mbiti. Tshaka (2007:541) seemed to be seriously concerned that people might abuse the notion of 'African' and therefore, he insisted that this term needs serious conceptual clarification and discussion. $\mathrm{He}$ unambiguously and unequivocally argued that an African is a person who is 'holistically rooted in the cultural setting from which he/she originated' - in this case, Africa. Therefore, he unapologetically states that while it is possible for a person to convert to a particular faith, one cannot convert to become an African!

Nonetheless, it is not always explicit what theologians mean when they use the terms 'African' and 'black' in theological circles and discourses, which reflect the concern raised by Tshaka. Tshaka argued that these notions are not obvious. They need to be critically discussed to achieve greater clarity. It becomes a deep concern when theologians and academics regard an African identity as 'obvious' without critical interrogation and reflection. Steve Biko (1978), who also contended for a more 'human face' in South Africa, did not ignore the tensions between racial and ethnic groups in South Africa. It is not possible to circumvent or ignore the challenge of what it means to be 'African' because it is only through understanding and appreciating one's 'Africanness' that South Africans will be able to conceive the emergence of a 'true humanity' (cf. Biko 1978).

In terms of the argument above, the author addresses in this article the tension and contestation of racial identities in the context of mission studies at public universities in South Africa. Mission studies is a field of study that includes mission history, mission theory and also mission praxis to address the impact and role of mission in the transformation of the society. Mission studies have been at the cutting edge of theology as they address issues of justice, reconciliation, racism, ecology and all issues of God's inhabited world. Nonetheless, mission studies have also, for centuries, served a particular community and its faith tradition. The author argues that in a post-apartheid context, it is déjà vu, disguised in a different form and shape.

The author critically discusses the articulation and expression of the notion of 'African' and 'black' in terms of the content, epistemology and pedagogical practices of mission studies at South African higher education institutions to address the challenge of social cohesion. The author commences with a critical discussion on the notion of 'African' and 'black' in apartheid as well as post-apartheid South Africa, focusing on the academic discourse. Subsequently, the author discusses the necessity of mission studies to be inclusive of all African identities. The author concludes with some thoughts on how to re-imagine the teaching of missiology in terms of its epistemology, curriculum and pedagogy.

\section{Mission education: Through the lens of African and Black theology}

It is apparent in most of the corpus of African theologians, about Africa, that their anecdotes, illustrations and examples reflect a particular culture in Africa at the expense of others. It is significant when Bosch (1974:1-22) as a missiologist wrote about the genealogy of Black theology that he refers to a Congolese catholic girl in the 1700s. Without any attempt to dispute such a fact, it is eccentric that he could not think of a case of 'protest' against suffering and oppression and marginalisation in the 1600s already by some of the Khoi or San people during the time of Dutch colonisation in the Cape (South Africa). Black theology - as Bosch (1974:2) himself refers to it - is a 'protest' movement against oppression and marginalisation. Certainly, an anecdote of one of the indigenous people, like the Khoi or San people, who protested against the settlement of the Dutch East India Company would have fit appropriately into this category. ${ }^{4}$ Therefore, the portrayal of 'Africans' as only through the culture and protest of a marginal and sectional part is not a matter that theology or missiology should leave unattested. Therefore, this article proposes a critical reflection on how theologians construe African tradition and culture so that it would not be too narrowly defined to include other African cultures that originated in Africa. ${ }^{5}$ The article interrogates the following topics: what did 'marginalised' or 'oppressed' refer to in apartheid, as well as in a post-apartheid South Africa. The author draws from not only various black and African theologians, but also other academics in the field of social and human sciences, and more importantly the anti-apartheid activists including Steve Biko who engages in issues of essentialism in social identity and multiculturalism.

The thesis of the article is based on the notion that 'essentialism' in social and racial identity does not assist students and teachers of mission in public universities. The fact that 'coloured' identity is not well-articulated in theological discourses creates a vacuum in the epistemological transformation of mission studies at public universities. This contribution is built on the theories of, among others, Bell Hooks who accentuated the constant contestation in university classrooms and contexts on 'who am I? and 'who are we?'. Although such questions are crucial and beg for answers, teachers of missiology should allow students to answer these questions in such a way that it creates space in the classroom where differences are acknowledged and respected. The article addresses mission studies and provides some contours, suggestions and markers for teaching missiology at public higher education institutions.

4.See the chapter 'Van Riebeeck en die inboorlinge' in Böeseken 1971.

5.Rodney Tshaka (2007) argues that African culture includes only those cultures that originated in Africa. 
The author follows the cue of the first former 'coloured' rector of the University of the Western Cape, Richard Van Der Ross, who provided a political-historical description of the suffering of 'coloured' people in South Africa. ${ }^{6}$ The author repudiates the idea of 'coloured' people being a race, but nonetheless argues that it constitutes a group of people who have a history (cf. Sonn 2015, in Van Der Ross 2015:1). The author is aware of the contestation, especially scholars who are drawing more from the cultures and various origins of 'coloured' people, for example, the Khoi, San or KhoiSan. However, Van Der Ross (2015:22) argues that although there are elements of Khoi, San in 'coloured' people, there are also elements of so many other races in them.

\section{A conceptual discussion: 'marginalised' and 'oppressed' in South Africa}

It is apparent in the discourse of anti-apartheid activists and theologians that the notions 'black' and 'African' are employed to protest the system of apartheid. These two notions created 'black' solidarity that would become a force in South Africa which would lead to the dismantling of the vicious systems of apartheid in South Africa. These two notions have also been interpreted to relate to the most vulnerable, those who were oppressed and marginalised as a result of the apartheid legislation. Therefore, the author discusses in this section these notions, with reference to 'black' and 'African' in the quest for conceptual clarity. It furthermore discusses the relevance and appropriateness thereof for the situation of the so-called 'coloured' people in a post-apartheid context.

\section{The concepts 'marginalised' and 'oppressed' during apartheid, South Africa}

The works of prominent African philosophers and theologians on the notion of 'black' and 'African' are included and discussed in this section. It is these notions that broadly address the issues of oppression and marginalisation during the years of apartheid in South Africa.

The most influential intellectual and anti-apartheid activist who has contributed to the discourse on 'blackness' in South Africa is Steve Biko. Biko refers to black people as those who are marginalised and oppressed. Biko jettisons the notion that 'black' has to do with skin colour as he states, 'being black is not a matter of pigmentation - being black is a reflection of a mental attitude' (Biko 2006:52). It is apparent from Biko's writings that he does not subscribe to the idea that there are 'variants' in black. Nevertheless, in a critical sense, his ideas were cluttered with 'anecdotes' and 'narratives' that essentially draw from the wells of the culture he is well acquainted with. ${ }^{7}$ This is evident when Biko (1978) narrates:

\section{See his book Van Der Ross (2015).}

7.However, in the bigger scheme of his work, it is evident that Biko proposes something different from a racialised society in a 'normal' situation.
When Africans drank, they would first relate to God by giving a portion of their beer away as a token of thanks. When anything went wrong at home, they would offer sacrifice to God to appease him and atone for their sin. There was no hell in our religion. We believe in the inherent goodness of men - hence we took it for granted that all people at death joined the community of saints and therefore merited our respect. (p. 2)

The illustration above confirms that although his anecdotes might be a convenient way to express 'Africanicity', drawing examples from his own cultural 'wells', which is the particular 'black' experience he belongs to, could construe, if exclusively used, Africanness as one particular cultural identity that would suppress other expressions thereof. ${ }^{8}$

Messina (1995:115) reminds us that during the apartheid years, the coloured group was regarded as 'black'. Especially in terms of the Black Consciousness Movement, 'black' had little to do with pigmentation (black skin) because black consciousness was a philosophy (Messina 1995:116). The South African Students Organisation (SASO) was an organisation that comprised students who were frustrated with the lack of progress in the National Union of South African Students (NUSAS) (at various public universities in South Africa) - an organisation that consisted mainly of white members. The South African Students Organisation was, therefore, an organisation that was open to all those who were oppressed and this includes African, Indian and coloured groups. Steve Biko became part of this organisation - and in the same way - he refers to blackness as those other than white.

Biko (1978:56) reflects in his discussion on 'intergroup conflicts' between segments in the black community that to be 'black' is more than only one cultural expression of one particular 'black' experience. However, more interesting is his (Biko 1978) observation of the rivalry and conflict between the different groups of 'blacks' in the 1970s in South Africa:

The importance of black solidarity to the various segments of the black community must not be understated. There have been in the past lot of suggestions that there can be no viable unity amongst blacks because they hold each other in contempt. Coloureds despise Africans because they, (the former) by their proximity to the Africans, may lose their chances of assimilation into the white world. Africans despise the coloured and Indians for a variety of reasons. Indians not only despise Africans but in many instances also exploit the Africans in job and shop situations. All these stereotype attitudes have led to mountainous inter-group suspicions amongst the black. (p. 56).

Biko (2006:56) presents a solution to the disparity among the 'black' community. He argues that all the members in the black community should realise:

- We are all oppressed by the system.

- That we are oppressed to varying degrees is a deliberate design to stratify us not only socially but also in terms of aspirations.

8.However, Biko deserves credit for not being naive of his own biases 
- Therefore, it is to be expected that in terms of the enemy's plan there must be this suspicion and that if we are committed to the problem of emancipation to the same degree, it is part of our duty to bring to the attention of the black people the deliberateness of the enemy's subjugation scheme.

- That we should go on with our programme, attracting to it only committed people and not just those eager to see an equitable distribution of groups amongst our ranks. This is a game common among our liberals. The one criterion that must govern all our action is commitment.

Nevertheless, Steve Biko refers in his work to the relevance of Black theology to respond to the apartheid situation. In South Africa, Allan Boesak became well known for his contribution to Black theology to address the theological justification of apartheid. Allan Boesak, as a 'coloured's theologian, also argues for a 'black response' during the apartheid years. However, for him, the answer lies not in the colour of one's skin, because all that are oppressed and marginalised and fighting against the oppressive system are 'black'. Allan Boesak wrote quite extensively on his understanding of blackness, and this article will not venture into his entire treatise on the matter; however, it is interesting as a black theologian how he, as part of the 'coloured' group in South Africa, also does not define black in terms of pigmentation, but rather in terms of oppression and marginalisation. Boesak (1977:27) defines blackness in South Africa as a, '... "non-white": a non-person, less than white, and therefore less than human'. He transcends the 'race' question: when he discusses the race problem as a matter of human dignity. 'Blackness is a reality that embraces the totality of black existence' (Boesak 1977:26). Boesak (1977:26) states that in terms of Black theology, being black serves as a decisive factor in a black person's expression of his or her belief in Jesus Christ as Lord. He also argues further, 'it is not hatred of white people that blacks have. It is white oppression they hate. And hate it they must... with all their hearts' (Boesak 1977:29).

Although, there is more literature that would attest to the idea of blackness inclusive of all those that were in solidarity with the black experience, these authors' views suffice. It is evident that 'blackness' during the apartheid era had a 'black solidarity' constituting those who experienced oppression, and marginalisation of the apartheid government. In terms of two prolific scholars - a black activist (Steve Biko) and a black theologian (Allan Boesak) - in the fight against apartheid, the term 'black' constituted African, coloured and Indian in terms of the apartheid racial classification.

\section{The concepts of 'marginalised' and 'oppressed' in post-apartheid South Africa}

The notions 'black' and 'African' came to have different variants after the abolishment of apartheid, and when a predominantly black government came into power, during the post-apartheid era, there was 'marginalisation' and 'oppression' of a different type. The South African historian Adhikari (2005) comments specifically on the state of 'coloured' identity in a post-apartheid South Africa:

The evidence indicates that many people who have gone beyond simply accepting racial categories as given are wrestling with questions about the extent to which they should express their identity as black, as African, as South African, as Coloured, as Khoisan, as descendants of slaves or whether they should make a stand on the principle of nonracism. (p. 186)

Adhikari (2005) provides an in-depth account of coloured identity under the white era domination as well as the postapartheid period. Adhikari (2005) asserts:

Coloured identity remained remarkably stable and experienced relatively little fundamental change in the way it operated throughout the era of white domination. The post-apartheid period has, however, witnessed significant and swift changes in the ways Coloured Identity manifests itself. (p. 162)

Adhikari (2005) discusses how 'coloured identity' manifests in post-apartheid South Africa. He mentions that suddenly in the wake of the first democratic elections, Nelson Mandela would urge the ANC to recognise 'coloured ethnicity'. He argues that this would be directly the opposite in terms of the discussion of black consciousness which transcends 'inter-group' and racial categorisation. This would, therefore, reject the 'non-racial' stance during the apartheid years. Adhikari (2005:177) believes that the ongoing appeal to coloured group consciousness can involve countering the non-racial stance of the movements during the 1970s and 1980s.

\section{He states (Adhikari 2005):}

The black peril tactics of the National Party during the 1990s, particularly in the run-up to the 1994 elections, were undoubtedly instrumental in heightening race consciousness within the coloured community. More recently, Democratic Alliance strategies for winning Coloured support have openly played on fears of African domination. The ANC also contributed to this process both by sidelining the UDF-affiliated anti-racist lobby of the Western Cape soon after it's unbanning and by directly soliciting Coloured support. (p. 177)

Adhikari (2005:177) argues that though 'overly racialized tactics' is on the decline, political parties still 'work with essentialist concepts of race' and 'exploit racial identifications'. It is evident through the work of Adhikari that there was a new move that would emphasise ethnic consciousness that deepens the 'racial' divide. Although the author argues for inclusion, the author does not argue for racial essentialism which is clear in Adhikari's (2005) historical and systematic description of the current 'racial' climate in South Africa. We have seen various organic intellectuals in the communities mobilising the so-called 'coloured' community through, for instance, identifying with their slave past, and trying to re-invent the Khoisan history, because of a deeply felt 'exclusivistic' tendency through actions of the new black government. 
The coloured community re-inventing its historical past is because of feelings of 'marginality' (Adhikari 2005:182), of 'betrayal among disillusioned former supporters of the antiapartheid movement'. Adhikari (2005:182) argues that coloured people regard themselves as the 'lowest in the pecking order of the new South Africa' because the African dominated government 'advances its racial constituency'.

It is evident that there have been significant changes within the 'black' community post-apartheid. Some African 'blacks' have become part of the 'elite' and, therefore, no longer relate to their previous 'black' experience. Therefore, even the socalled 'coloured' people experience black oppression and marginalisation, whereas others in the 'black' do not. The same condition is noted for the African and Indian community. Therefore, while the new government places focus on Africans in particular, Mbembe (2007) argues that it has become more difficult to decide who is 'black' ${ }^{10}$ The answer should be sought through the identification of 'oppression' and 'marginalisation' rather than based on pigmentation. Mbembe does not suggest that those being oppressed and marginalised should wait for government intervention, which involves focussing on a particular 'African' agenda, but he calls for a new black solidarity.

Mbembe (2007:147) argues that the new government does not conform to the ideals of Biko and others who fought for racial justice and reconciliation. The so-called coloured people suffer the brunt of it, and therefore it curtails the ideal of Steve Biko and other anti-apartheid activists for a non-racial society, in which all cultures would be celebrated. Mbembe (2007:147) therefore states, 'freedom for black South Africans will be meaningless if it does not entail a commitment to freedom for every African, black or white'.

What are therefore the options that the so-called 'coloured' people have in a post-apartheid South Africa? Adhikari (2005) suggests that one option should be for a 'non-racial' position. However, instead of fostering a non-racial position, he (Adhikari 2005:184) espouses a 'rainbow' position 'that accepts the reality of racial and ethnic distinctions and their identity as coloured but embraces the multiculturalists precepts that all communities be accorded respect and receive equal treatment'.

\section{Coloured people as Africans?}

While the notion 'black' particularly refers to oppression and marginalisation, the notion 'African' articulates the cultural expressions of the inhabitants of Africa better. Although it is important to discuss the 'blackness' of the so-called coloured people during apartheid and post-apartheid South Africa, it

10.'Since Biko's death, blacks in South Africa have secured equal citizenship rights. The constitution outlaws racial discrimination. Today there are significantly more blacks in the middle and upper classes than there were 30 years ago. In the words blacks in the middle and upper classes than there were 30 years ago. In the words of a black female entrepreneur, some have more than a luxury vehicle. They own more than one home and can afford private school education for their children, who own cellphones ... The meaning of race and the nature of racial identity are now far more complex and ambiguous than they have ever been. Who is "Black" "Afrikaner", "white", "coloured", or "Asian" is no longer entirely pre-fixed. The discourse in which South Africans represent race relations are [sic] changing (Mbembe 2007:142). is further of paramount importance to discuss the cultural appreciation of the so-called coloured people within the African discourse and literature.

It is apparent that the so-called 'coloured' people belong to what is referred to as 'black', but it is not always apparent whether they are 'African' especially in terms of African theology. The author particularly refers to an example from the writings of Tshaka (2007) in his article, 'African, you're on your own!', in which he unreservedly positions himself with some intellectuals:

[A] African is not someone who is African by reason of being patriotic but rather an African is one who is holistically rooted in the cultural setting from which he/she originated. (p. 541).

Tshaka (2007:541) also refers to the argument of Kwesi Kwaa Prah, 'African[s] are people who's [sic] origin, cultures, and history is derived from the African continent'. Nevertheless, in terms of what is an African, the former president of South Africa, Thabo Mbeki (1996), articulates as follows:

I am an African. I owe my being to the Khoi and the San whose desolate souls haunt the great expanses of the beautiful Cape they who fell victim to the most merciless genocide our native land has ever seen, they who were the first to lose their lives in the struggle to defend our freedom and independence and they who, as a people, perished in the result. Today, as a country, we keep an inaudible and audible silence about these ancestors of the generations that live, fearful to admit the horror of a former deed, seeking to obliterate from our memories a cruel occurrence which, in its remembering, should teach us not and never to be inhuman again. (n.p.)

This discussion on African identity should also be conducted with caution, especially in light of comments made by Xolela Mangcu (2008). He (Mangcu 2008) argues that:

$[T]$ here was no essentialist African identity that was pure and untouched by the cultures with which one interacted ... In particular, Biko's concept of a joint culture comes from blackwhite or African-European interaction. (pp. xiii-xiv)

Therefore, the discussion of who is African involves being cautious that cultures are not static but are also constantly undergoing change and depend on societal changes and also contextual ones. Maluleke (2001:26) warns that there is no united, homogeneous Africa or African identity - 'there are and should be many and various ways of being an African'.

It is in this regard that Mbembe (2016:34) raises the concern of Fanon stating the notion of 'Africanisation' as that generating and spawning violence and oppression of Africans in the hands of 'foreigners' (and not fellow compatriots). Mbembe (2016) writes in this regard:

Fanon was ill at ease with calls for 'Africanisation' because calls for 'Africanisation' are, if not always then in most instances, haunted by the dark desire to get rid of foreigners - a dark desire which, Fanon confesses, made him 'furious and sick at heart'. It made him furious and sick at heart because the foreigner to be gotten rid of was always a fellow African from another nation. And because the objective target of 'Africanisation' was a fellow 
African from another nation, he saw in 'Africanisation' the name of inverted racism - self-racism if you like. (p. 34)

The argument of Fanon relates also per se to all other Africans who are not looking the same as you, speaking the same language as you do and not following a culture you are used to, but, as Tshaka (2007:533-548) puts it, has its roots in Africa. Maluleke (2010:377) states, 'African Christianity is no longer about skin colour, origins and geographical locations of its practitioners. It is a way of being Christian in the world today'.

\section{David J. Bosch's Transforming Mission (1991): Context and culture}

This section discusses the seminal work of David J. Bosch (Transforming Mission) and brings up his conversation on the new emerging paradigm of mission, in particular, mission as 'contextualization' and 'inculturation' in conversation with the ideas of Biko regarding 'true humanity'. His work is an appropriate missiological resource to serve as a response to the inclusion of the 'coloured' people's story within missiology. This would be an important role that mission studies should play, especially in light of Biko's remarks on the 'negative role' and the contribution of missionaries in the 'oppression' and 'marginalisation' of blacks in the South African context. Biko (2006:61) argues that it was white missionaries who looked down upon 'blacks' and their cultures by calling them 'savages'.$^{11}$ The author argues that Bosch's discussion on a new way of conducting a mission could 'redeem' the past actions and wounds ${ }^{12}$ caused by missionaries. ${ }^{13}$ Biko (2006) concurs with Bosch on listening to 'marginalised' communities and allowing them space to 'interpret' their pain:

We are aware of the terrible role played by our education and religion in creating amongst us a false understanding of ourselves. We must, therefore, work out schemes not only to correct this but further to be our authorities rather than wait to be interpreted by others. Whites can only see us from the outside and as such, can never extract and analyse the ethos in the black community. (p. 57)

11.Biko states that it was the white missionaries that, ... describe black people as thieves, lazy, sex-hungry etc., and because he equated all that was valuable with whiteness, our churches through our ministers see all these vices I have mentioned above not as manifestations of cruelty and injustice which we are subjected to by the white man but inevitable proof that after all the white man was right when he described us as savages.

12.Bosch (1991:301) argues, 'the problem was that the advocates of mission were blind to their own ethnocentrism. They confused their middle-class ideals and values with the tenets of Christianity. Their views about morality, respectability, order, efficiency, individualism, professionalism, work, and technological progress, having been baptized long before, were without compunction exported to the ends of the earth. They were, therefore, predisposed not to appreciate the cultures ends of the earth. They were, therefore, predisposed not to appreciate the cultures
of the people to whom they went - the unity of living and learning; the of the people to whom they went - the unity of living and learning; the
interdependence between individual, community, culture, and industry; the profundity of folk wisdom; the proprieties of traditional societies - all these were swept aside by a mentality shaped by the Enlightenment which tended to turn people into objects, reshaping the entire world into the image of the West, separating humans from nature and from one another, and "developing" them according to Western standards and suppositions' (cf. Sundermeier 1986:72-82).

13.In one of my recent papers, I state, 'Bosch appreciates that the deep-rooted paradigm of mission thought and practice is not easy to shake off and therefore he poses the question: "Whither mission" if there has been so much damage done in porms "mission" "that even the concept of mission is much damage done in corms of "ission" that even the concept of mission is seen as tantamount to its missionary task in the wold, but rather to use the following beacons to ensure its missionary task in the world, but rather to use the folowing beacons to ensure that the church does not lose its credibility. He argues that the credibility of the church's mission should be assessed through the salvific events of Jesus Christ' (Baron 2019:17)
Bosch (1991) argues in his book Transforming Mission that mission should be contextual. However, in terms of the situation of the so-called coloured people and their experiences in a post-apartheid situation, the question should be posed: how contextual is 'contextual' if it does not include and sufficiently address and articulate 'coloured identity' as an oppressed group in the South African context, taking into account that Bosch was a South African missiologist?

Bosch (1991:453) regards the local community as the 'primary agents', not missionaries (who often controlled the process). Vatican II made it clear that the universal church only finds true existence in the 'particular' church. Bosch (191) describes inculturation as:

[T] he gospel being enfleshed', 'embodied' in a people and its culture of a 'kind of ongoing incarnation' in a distinct form from any model that had been in vogue for over a thousand years. (p. 454)

Bosch (1991) states:

$[O]$ ne may never use the term 'inculturated'. Inculturation remains a tentative and continuing process, not only because cultures are not static but also because the church may be led to discover previously unknown mysteries of the faith. (pp. 455-456)

Nonetheless, Bosch (1991) defines inculturation as follows:

We need an exchange of theologies in which Third World students continue (as they have been doing for a long time) to study in the West, but in which Western students also go to study in Third World context - in which one way traffic, from the West to the East and the South is superseded, first by bilateral and then by multicultural relationships. (p. 456)

Nevertheless, Bosch's (1991) work Transforming Mission and conceptualisation on 'contextualisation' and 'inculturation' do not go uncritiqued. Kim (ed. 2000) argues that Bosch's theology of mission did exactly the opposite to what he proposed - he does not give sufficient attention and interest in 'indigenous spiritualities' or 'the spiritualties of indigenous people' although he states the following:

One should, again, see oneself as a child of Mother Earth and as sister and brother to other human beings. One should think holistically, rather than analytically, emphasize togetherness rather than distance, break through the dualism of mind and body, subject and object, and emphasize 'symbiosis'. (pp. 172-179)

\section{A 'colourful' missiological curriculum: In a quest for decolonization?}

It is important to note the works of Biko (2006), Mangcu (2008), JNJ (Klippies) Kritzinger (2008) and Bosch (1991) on the arguments for 'beyond pigmentation', 'black solidarity' and 'true humanity'. These notions will assist missiologists to re-imagine missiological curriculum. It will also assist missiologists to show greater sensitivity and approach missiology with greater inclusivity. However, in this section, 
the author will specifically focus on the current status quo of missiology about the discussion in the article on an inclusive African and black identity, in which 'coloured identity' serves as a case study.

Smith and Domeris (2014:157) include the work of Bosch (1991) as one of the standard student textbooks that are used at South African universities in the field of missiology. This section would be crucial, as it will contribute to the whole question of whether the 'contextualised' missiology is speaking to the likes and ideas of inclusive African missiology.

The WCC' mission statement 'Together towards Life Mission and Evangelism in Changing Landscapes' (Keum 2013) states in article 2, 'mission being at the heart of the triune God and the love which binds together the Holy Trinity overflows to all humanity and creation'. The WCC underlines mission's focus on all of creation as an issue that needs serious attention and reflection. The WCC mission statement also refers to people on the margins who should perform a crucial role in missional transformation. However, this has not assisted South Africans immensely; there is still some degree of being 'marginalised' and some degree of being 'oppressed'. The WCC (2013) contends that:

[A]ll that participate in God's mission should do so in unity, overcoming the divisions and tensions that exist among us, so that the world may believe and all may be one (Jn 17:21). (n.p.)

It emphasises that 'the church and the community of Christ's disciples should be an inclusive community (WCC 2013: Art. 10)'. The WCC reiterates the context of the church as multi-religious and multicultural: and that this warrants the church to bring people of the world into 'a greater awareness of one another's identities' and should commit to 'cross-cultural communication' (WCC 2013:Art. 9).

Recently, the notion of oikosmissiology has been used by various missiologists to explain God's concern for the whole inhabited world. While the cosmos, economy and some parts of God's creation, and challenges in the world, have been excluded in the past, there seems to be a greater sensitivity to be inclusive. This is based on the notion of missio Dei that denotes God's indiscriminate work on the earth. This notion of oikosmissiology becomes useful for the argument that all cultures and marginalised communities, including the socalled coloured community, should be valued, and through intentional engagement be included and celebrated within African culture and discourse in a post-apartheid situation.

Teachers of mission should embrace all epistemologies and intentionally reflect on all African cultures in their content and curriculum. African mission theology should also include anecdotes and interlocutors from various African cultures. Nonetheless, more than this is required in the structural nature of the syllabuses and modules. The involvement of individuals of various cultures in the development of the discipline is needed for it to remain 'colourful' and 'contextual'. The missiologists should still conduct mission from the margins, but with sensitivity not to 'generalise' but to always be aware of the 'colourfulness' of the South African context.

However, some initiatives have the potential to construct a more inclusive Africanism (cf. Biko 1978). Nico Botha, an emeritus professor of missiology, introduced a module at the University of South Africa during his tenure. The module 'Redeeming memories' envisaged and attempted to enter the field of mission historiography in which students were assessed on constructing their history. This would be one of the success stories of mission studies and its contribution to eradicate all forms of oppression and marginalisation in South Africa. Other attempts include the inclusion of the missions work of a 'coloured' ${ }^{14}$ a slave, ${ }^{15}$ and an 'early black' ${ }^{16}$ missionaries, other than white, which serves as good resource material in the pursuit to be inclusive and colourful.

It is Maluleke (2017) who quite recently drew on the work of a 'coloured' (Allan Boesak) theologian but referred to him as a black ${ }^{17}$ theologian. This gesture contributes volumes to the notion of 'blackness'. He wrote on the life of a 'coloured' person and contributed to the discourse on black oppression in South Africa using a narrative and biographical genre. This became part of the 'missiological' society and is published in the most highly esteemed journal, Missionalia, in the field of missiology in South Africa. However, he is also a theologian who has written quite extensively on the field of missiology as an African, black theologian and as a leading scholar; his inclusion of 'coloured' referring to him as a 'black' theologian is therefore significant.

Kritzinger (2002:144-173), a student of David J. Bosch, discussed how mission agents should approach mission in the current age. His metaphor of 'roots and wings' (Kritzinger 2002:145) is important in discerning the way forward for missiological education. It should continue to spread its tentacles deeper into the South African context, which will curtail the 'oversimplification' of 'pain' and 'suffering' and the often generalised labelling of the 'marginalised' (as a monolithic concept). However, missiologists should also not be reluctant but prophetic to 'name' (unmask) those 'pains' and 'sufferings' from all avenues of the 'black' and 'African' corners, even in times when it is not fashionable to do so.

Kritzinger (2002) argues that the Christian mission has at least three questions to pose: 'who am I? (identity); who are we? (community); and, who is Jesus for us today? (Christology)'. This article deals with the first and second questions. It calls therefore for a deeper commitment to engage other marginalised communities. The first part of this article reflects on the issue that although African and Black

14.See the missionary biography of Jan M. Kok in the 1700 s in South Africa in the work of Schoeman (2005:42-56); it serves as a good resource material.

15.A slave, called Maart of Mosambiek (Schoeman 2005:57-67)

16.In this instance, 'black' refers to African black in terms of apartheid racial classification (Schoeman 2005:138-157).

17.Maluleke (2017:61) states, 'yet it is fair to add that had Strydom succeeded in assassinating Boesak, black South Africa would have experienced a loss akin to that experienced when Steve Biko inexplicable [sic] died in police attention'. 
theology has much to offer to the discussion and is able to dismantle the essentialism approach in theology on social identity, it has not done enough from a pragmatic perspective to demystify the notions of marginalisation and oppression in post-apartheid South Africa. It should show more sensitivity to those who are understood in terms of the racial category of South Africa as the 'coloured' communities and include their biographies, anecdotes, aesthetics in the 'colourful' African enterprise of mission education. The author's main argument rests on the thesis of Achille Mbembe. He (Mbembe 2016) states:

$[A]$ process of knowledge production that is open to epistemic diversity. It is a process that does not necessarily abandon the notion of universal knowledge for humanity, but which embraces it via a horizontal strategy of openness to dialogue among different epistemic traditions. (p. 37)

The inclusion of 'coloured' people's history, their 'marginalisation' and 'painful' memories would allow those segments of the black and African community to 'come to themselves'. Steve Biko (1978) states:

The first step ... is to make the black man come to himself; pump back life into his empty shell; to infuse him with pride and dignity, to remind him of his complicity in the crime of allowing him to be misused and therefore letting evil reign supreme in the country of his birth'. (p. 31)

Ngugi (1981:87) in his book Decolonizing the Mind also argues that decolonisation means that we start with ourselves but that we 'see ourselves clearly in relationship to ourselves and other-selves in the universe'. Kritzinger (2002:154) argues that 'credible mission in the first place asks: Who am I...', which is the primary purpose of mission. It should be a window for all cultures to retrieve its own 'identity' within the collective identity. He cautions (Kritzinger 2002):

Unless we do this, and develop a growing reflective competence, the ability to work with ourselves and become more authentic and peaceful with ourselves, we are in danger of transferring our hang-ups and frustrations to other people, thus adding to their burdens. (p. 154).

Krog (2009) states:

[When] I read about the Nigerian gods and deities, I think, Jesus, maybe not, and when I read that the missionaries were perturbed when they arrived in southern Africa because they found 'no idols to shatter, no altars to seize, no fetishes to smash', in contrast to the rest of Africa, then I think, maybe the particular kind of interconnectedness I have come to know is confined to the southern part of the continent. 'Would it not have come from the north with the black people moving down?' I thought about it, and my guess is that this all-encompassing philosophy, this interconnectedness with 'the wholeness of life' - religious and secular, spiritual and material, which can never be compartmentalized or understood in isolation from one another - was inherited from the First people and population, which lived mostly in southern Africa. Especially because it implies a cosmological dimension, a human and non-human world that encapsulates plants, animals, a spiritual god and ancestors. There is enough evidence in the records about the San and Khoi suggesting such a sophisticated worldview. I believe that just as much as their click sounds have survived in our African languages, so this broad philosophy of interconnectedness towards something more spiritual, more whole, more towards the potential power of everything, has survived in the minds of the speakers of those languages. (p. 184)

The article argues that missiology discourse will open up more space(s) for other marginalised and oppressed groups in South Africa, with reference to the so-called 'coloured' racial identity and category in South Africa who will become an added 'interlocutor' (discussion partner) that will shape all those who are students of missiology, and also lecturers in missiology. Kritzinger (2002:156) argues that we should grant all marginalised people the privilege to interrupt our conversations and accord them the status of 'trump card' over other cards.

Mission education should allow students to grapple with 'coloured identity' history and its effects on the spirituality and religion of the so-called 'coloured' people in the Cape colony - and their experiences of God during pre- and postcolonial times. Hooks (1994) as a black scholar and writing on 'Education as a practice of freedom' cites an example from her pedagogical practice that would support the thesis of this article:

When I teach Tonni Morrison's The Bluest Eye in introductory courses on black women writers, I assign students to write an autobiographical paragraph aloud to the class. Our collective listening to one another affirms the value and uniqueness of each voice. (p. 84)

This would also be liberating to the so-called 'coloured' students who are grappling with their own social identity as being African and black. It is interesting to note, in the way that Kritzinger (2002:158) would describe himself as an African, as he would need to show that from the treatise of a "well-known and highly respected "African" leader of the Pan Africanist Congress (PAC)' to validate and confirm his 'Africanness'. He (cf. Gerhart 1978) argues, therefore, that it is precisely the words of Robert Sebukwe that confirm his 'African' identity:

We aim, politically, at the government of the Africans by the Africans, for the Africans, with everybody who owes his [sic] only loyalty to Africa and who is prepared to accept the democratic rule of an African majority being regarded as African. (p. 195)

Maluleke (2010:375) argues that African Christianity is 'plural not singular'. He (Maluleke 2010:375) states that 'it is not the most homogenous of Christianities. If anything, it is a cacophonous, colourful cluster of contending Christianities all hidden under the misleading singular name - "African Christianity"'. Therefore Maluleke (2010:376) argues, 'Much research remains to be done' to display the myriad forms of African Christians. This makes space for a particular 'coloured identity' within African spirituality which needs to be documented in terms of metaphors, stories, anecdotes and other relevant ways to bring the experience and oppression and marginalisation of the coloured group in the domain of mission theology. 
Students should be able to make connections between what they are learning 'to their overall life experiences' (Hooks 1994:19). Appiah (1994:2) in his book In My Father's House: Africa in the Philosophy of Culture argues that in his father's house [Africa] there are many mansions - meaning that there are various ways of being African. Nonetheless, Kritzinger (2008) refers to Biko's arguments concerning the transformation of society - and his solution to the 'race' problem in South Africa. Kritzinger (2008), in his engagement with the treatise of Biko (2006) in the book, I Write What I Like, refers to his dialectic between white and black. He accentuates that Biko does not argue for the preference of one race over or against another. However, that racial integration cannot take place on whites' terms but can only happen on 'African'18 terms. Kritzinger (2008:95) argues that Biko does not envisage a society where one or the other [race] would 'rule' over another, but on the contrary ... a transformed society, in which white people would be welcome if they were prepared to let go of racism, learn to respect black people and sit down side by side with them at a table decorated in African style, not claiming any special privileges on their terms but joining on African terms.

Therefore, in Kritzinger's analysis, Biko has never argued for 'reverse' racism, but something that transcends 'race'. Kritzinger (2008:95) explains that for Biko the thesis is whiteness, the anti-thesis 'blackness'. However, what he calls for is more than this but a synthesis that will translate into 'true humanity'. Nonetheless, what will happen to whites, when all is 'normal'? Biko states that they will be part of 'true humanity'. It is, therefore, important to note that all those in Africa belong to the discussion on 'values' in Africa although only in a situation (in terms of Biko's argument) when everyone is on equal footing.

\section{Mission studies in higher education: A future ethical perspective}

This article offers at least three conceptual contours in the teaching of missiology at South African higher education institutions. It is important that the teachers in missiology should approach it with a balance in pedagogical practice. It should combine experiential approaches with analytical ones. Current mission discourse supports the notion that knowledge is rooted in praxis, and can be arrived at through experience. These experiences take on the form and shape of narratives - particularly from marginalised groups and should be used to the advantage of teachers and students of missiology. Hooks (1994) who built her work on that of Paolo Freire, particularly on his idea of 'conscientisation', argues that the inclusion of the 'experiences' of oppression should be equally important as an analytic study thereof. Hooks (1994:90) engages the issue 'authority of experience'. However, Hooks also reflects on the one-sidedness that might occur when 'experience' is the only qualifying factor to engage on

18. Kritzinger points out the slight change of words used by Biko, from "black' to 'African'. Kritzinger argues that this might be Biko's suggestion on conceptualising a 'normal' (human face) South Africa. issues of oppression. However, the context from which she confronts the issue of oppression is from her own experience where 'experience' is argued to be too 'emotional' and not perceived as a 'sound' contribution to the academic enterprise. Therefore, her approach is to highlight and accentuate the crucial contribution that 'experience' can provide to the discussion of oppression as opposed to a pure analytical discussion on it.

Hooks is also conscious of the practice of essentialism that might occur because those with experience of marginalisation and oppression would argue that others without experience do not qualify to contribute meaningfully to the discussion. Her argument is exactly what everyone should contribute, but her preference is obvious when she has to decide the characteristics of a lecturer to teach on pain, suffering and marginalisation. Hooks (1994:73) states that 'no education is politically neutral'. ${ }^{19}$ Hooks (1994) suggests that in a 50-50 situation where she has to choose between a white or black professor to teach on African American critical thought, she would prefer a progressive black professor:

I sincerely believe that I would have learned even more from a progressive black professor, because this individual would have brought to the class that unique mixture of experiential and analytical ways of knowing - that is, a privileged standpoint. (p. 90)

Her preference is captured recently by McKaiser (2016):

How can a racist even begin to recognise the full humanity of a black person if they are bombarded by pedagogical messaging that black people are less capable of knowledge production than [sic] white people are? (n.p.)

Therefore, one seems to understand the sentiments of Hooks and McKaiser that 'experience' of pain and suffering is important, especially in situations where there are only discussions on it in classrooms in a mere abstract manner and reasoning that would lead at times to the kind of 'generalisation' and 'oversimplification' of marginalisation and oppression, as the author argues in this article.

Achebe (2000), an African novelist, advocates in his book Home and Exile for the 'balance of stories'. He introduces in his introductory chapter the memories of his childhood home in Nigeria. However, he moves on to describe an incident that spiralled out of control in one of his university classes when he was a student in London. The situation went out of control when his fellow students were furious at an English professor because the author of a novel that they were supposed to read did an injustice to the memory of their hometown (Nigeria). Life in Nigeria as narrated by that English novelist was not close to their description of life in Nigeria. Therefore, Achebe (2000) states:

I did indeed read on my own, a few 'African' novels by such writers as Rider Haggard and John Buchan. But I did not connect to Africa in those riveting adventure stories among savages even remotely with myself or my homeland. (p. 31)

19.See Venter (2012:49): "knowledge is not stable, objective, neutral, and innocent'. 
The narrative of Africa as narrated by European novelists was about men, '... in chains, captives without power'. He makes the point that 'cruelty can be paraded in many disguises through the avenues of literature by all manners of dubious practitioners' (Achebe 2000:34).

Achebe (2000:41) reflects his discontent, discomfort and agitation with a story on Africa that others construe to be his story!

He was eventually at a later stage 'shortlisted' (cf. Achebe 2000:49) by renowned novelists as one who can authoritatively and legitimately narrate about Africa. However, he complains and repudiates such a 'truncated' list, arguing that the list should be a 'legion' of those who should narrate about Africa. He argues that for Africans to narrate about Africa, various African stories should be told, and that one story is not enough! It is, therefore, arguably so that 'African is African, as far as it expresses all Africans' (Baron 2019). Louw (2010:1) quotes Makgoba (1997:199), 'it is not about excluding Europeans and their cultures, but about affirming the African culture and its identity in a world community'. Makgoba (1997) defines and describes Africanisation as follows:

It is not a process of exclusion, but inclusion ... [I]t is a learning process and a way of life for Africans. It involves incorporating, adapting and integrating other cultures into and through African visions to provide the dynamism, evolution, and flexibility so essential in the global village. 'Africanisation' is the process of defining or interpreting African identity and culture. (p. 199)

Nevertheless, in conclusion, mission education, especially at public universities, should transform also on an epistemological level - to include all African cultures and identities. Venter (2012:49) argues that previously some faculties of theology in South Africa were established because of a 'narrow ecclesial motive' and at times only to the 'advancement of "one Christian tradition"'. However, Venter (2012:50) states as one of three ${ }^{20}$ reasons, why theological or religious knowledge is advancing the academy, the fact that the nature of theological or religious knowledge should be that of 'representation'. He, therefore, makes a crucial point as to how the nature of the knowledge should ultimately represent all epistemic communities within South Africa.

McKaiser (2016) challenges the argument that academic freedom should be conceded in the discourse on decolonisation. He argues that such an argument provides a license for the perpetuation of epistemological injustice and epistemic violence. He, consequently, argues that although academics might argue that freedom of expression should be protected at all times, it permits epistemic violence and injustices to grow rampant without being held accountable for epistemic violence against black people. He states (McKaiser 2016):

The South African University reproduces hegemonic identities instead of eliminating hegemony, and yet many of us defensively pretend that our alma maters are exemplars of freedom. (n.p.)

20.The other two are as follows: (1) knowledge should be in service of the good life and (2) it should not only be embodied in text but practices and woven into the institutional structures (cf. Venter 2012:50).
McKaiser (2016) argues that academic freedom is the reason why epistemic violence takes place. Therefore, there should be policies that address this, although only for the interim to bring in the future epistemic justice in higher education institutions. He (McKaiser 2016) laments:

If my teachers and lecturers had exercised their academic freedom with a greater sense of social responsibility about what it means for an academic to be aware of and responsive to the context within which they exist, I would [have] surely be[come] more familiar today with black thought and the thoughts of women than I am with, the thoughts of dead European men. Sadly, the South African academy remains a colonial outpost. (n.p.)

Hooks (1994:30-31) argues that 'the classroom should challenge us, not make us comfortable in our own identities' and 'those that want to teach to "transgress" will not only see the classroom as a "safe" space ... buta place of "uncomfortable realities"” (Hooks 1994:39).

Venter (2012:48) reflects on the rationale for universities to include the discipline of theology at public higher education institutions. He argues that it is a theology that should educate students in a way that 'may open new insights into the human and cosmic condition', and also particularly contribute to the 'social well-being' and 'non-discriminatory inclusion'. This would, therefore, provide a good basis for the main argument of the article that teaching should be inclusive, experiential and multicultural, in its epistemology, pedagogy and curriculum.

\section{Conclusion}

The problem with studies related to this topic is that highlighting the distinctiveness of all of the oppressed might become an issue of particularities and come across as advancing racial essentialism (which this article is arguing against), whereas this article does not aim to do this but rather to raise the alarm and accentuate the core business of missiology to take all epistemic communities seriously. This should be done at epistemological, pedagogical and curricula levels. The author uses one case study 'coloured identity' to argue for 'multiculturalism' in mission studies, and that teachers of missiology should always move beyond their frame of reference and become conscious and intentionally include the narratives, epistemologies of other Africans and blacks in South African higher education. The danger always lies therein, that a focus on 'coloured' as an identity to be included might also lead to an imbalance of the scale if it leads to essentialism, and therefore such a caution at the end of this discussion is necessary to lead to the continuous vicious cycle of essentialism of social identities.

\section{Acknowledgements Competing interests}

The author declares that he has no financial or personal relationships which may have inappropriately influenced him in writing this article. 


\section{Author's contributions}

E.B. is the sole author of this research article.

\section{Ethical considerations}

This article followed all ethical standards for a research without direct contact with human or animal subjects.

\section{Funding information}

This research received no specific grant from any funding agency in the public, commercial or not-for-profit sectors.

\section{Data availability statement}

Data sharing is not applicable to this article as no new data were created or analysed in this study.

\section{Disclaimer}

The views and opinions expressed in this article are those of the author and do not necessarily reflect the official policy or position of any affiliated agency of the author.

\section{References}

Achebe, C., 2000, Home and exile, Canongate, London.

Adhikari, M., 2005, Not white enough, not black enough. Racial identity in the South African coloured community, Ohio University Press, Athens, GA.

Appiah, K.A., 1994, In my father's house: Africa in the philosophy of culture, Oxford University Press, New York.

Baron, E., 2019, 'The call for African missional consciousness through renewed mission praxis in URCSA', Studia Historiae. Ecclesiastiae 45(3), 1-13.

Biko, S., 1978, I write what I like, Picador Africa, Johannesburg.

Biko, S., 2006, I write what I like, Picador Africa, Johannesburg.

Boesak, A.A., 1977, Farewell to innocence. A socio-ethical study on Black Theology and power, Orbis Books, New York, NY.

Böeseken, A.J., 1971, Avontuur in die vreemde. Die verhaal van Jan van Riebeeck, Tafelberg, Kaapstad.

Bosch, D.J., 1974, 'Currents and crosscurrents in South African black theology', Journal of Religion in Africa 6(1), 1-23. https://doi.org/10.1163/157006674X00130

Bosch, D.J., 1991, Transforming mission. Paradigm shifts in Theology of mission, Orbis Books, New York, NY.

Gerhart, G., 1978, Black power in South Africa. The evolution of an ideology, University of California Press, Berkeley, CA.
Hooks, B., 1994, Teaching to transgress. Education as the practice of freedom, Routledge, New York, NY

Keum, J. (ed.), 2013, Together towards life: Mission and evangelism in changing landscapes. With a practical guide, WCC Publications, Geneva.

Kim, K., 2000, 'Post-modern mission', International Review of Mission 89(353), 172-179.

Kritzinger, J.N.J., 2002, 'A question of mission - A mission of questions', in M. Karecki (ed.), The making of an African person: Essays in honour of Willem Saayman, pp. 144-173, SAMS, Pretoria.

Kritzinger, J.N.J., 2008, 'Liberating whiteness: Engaging with the anti-racist dialectics of Steve Biko' in C.W. Du Toit (ed) The legacy of Stephen Bantu Biko. Theological challenges, pp. 89-113, Thabang Printers, Pretoria.

Krog, A., 2009, Begging to be Black, Random House Struik, Cape Town.

Louw, W., 2010, 'Africanisation: A rich environment for active learning on a global platform', Progressio 32(1), 42-54.

Mckaiser, E., 2016, Epistemic Injustices: The dark side of academic freedom, viewed 17 July 2019, from https://www.iol.co.za/news/epistemic-injustices-the-darkside-of-academic-freedom-2029747.

Maluleke, T.S., 2000, 'The rediscovery of the agency of Africans: An emerging paradigm of post-cold war and post-apartheid black and African theology', Journal of Theology for Southern Africa 108, 19-37.

Maluleke, T.S., 2001, 'Identity and integrity in African theology: A critical analysis', Religion and Theology 8(1), 26-39. https://doi.org/10.1163/157430101X00026

Maluleke, T.S., 2017, 'The making of Allan Aubrey Boesak. Theologian and political activist', Missionalia 45(1), 61-76. https://doi.org/10.7832/45-1-224

Mangcu, X., 2008, To the brink: The state of democracy in South Africa, UKZN Press, Pietermaritzburg.

Mbeki, T., 2003, 'I am an African', Sowetan, 18 June, p. 17.

Mbembe, A.J., 2007, 'Biko' testament of hope', In C. Van Wyk (ed.), We write what we like (pp. 135-150), Wits University Press, Johannesburg.

Mbembe, A.J., 2016, 'Decolonizing the university: New directions', Arts and Humanities in Higher Education 15(1), 29-45. https://doi.org/10.1177/1474022215618513

Messina, E., 1995, 'Kleurlinge is ook swart' swartbewustheid in die Wes-kaap tot 1977', Kronos 22(3), 115-140.

Schoeman, K., 2005, The early mission in South Africa. Die Vroeë Sending in Suid Afrika, Protea Boekhuis, Pretoria.

Smith, K.G. \& Domeris, B., 2014, A student's A-Z of theology, SATS Press, Johannesburg.

Sonn, F., 2015, 'Foreword', in In our own skins: A political history of the coloured people, p. 1, Jonathan Ball Publishers, Johannesburg.

Sundermeier, T. 1986. Konvivenz als Grundstruktur Ökumenischer Existenz Heute 1 pp. 49-100, s.n., München.

Tshaka, R.S., 2007, 'African, you are on your own! The need for African Reformed Christians to seriously engage their Africanity in their Reformed Theologica Reflections', Scriptura 96(2007), 533-548. https://doi.org/10.7833/96-0-1173

Van Der Ross, R., 2015, In our own skins. A political history of the coloured people, Jonathan Ball Publishers, Cape Town.

Venter, R., 2012, 'Theology, the post-apartheid university and epistemological transformation: Intimating the shape of the challenge' in R. Venter \& F. Tolmie (eds.), Transforming theological knowledge. Essays on theology and the university after apartheid, pp. 45-72, Sun Press, Stellenbosch.

Wa Thiong'o, N., 1981, Decolonizing the mind, Heinemann Publishers, London.

World Council of Churches (WCC), 2013, Together towards life: Mission and Evangelism in changing landscapes, viewed 10 March 2019, from https://www.oikoumene.org/ en/resources/documents/commissions/mission-and-evangelism/togethertowards-life-mission-and-evangelism-in-changing-landscapes. 